Archives of Agriculture and Environmental Science

\title{
Production economics of Ginger (Zingiber officinale Rose.) in Salyan district of Nepal
}

\author{
Nobel Acharya ${ }^{1^{*}}$, Binod Acharya ${ }^{2}$, Surya Mani Dhungana ${ }^{3}$ and Vivek Bist ${ }^{4}$ (D) \\ ${ }^{1}$ Department of Agricultural Extension and Rural Sociology, Agriculture and Forestry University, Rampur, Chitwan, NEPAL \\ ${ }^{2}$ Department of Agricultural Economics and Agribusiness Management, Agricultural and Forestry University, Rampur, Chitwan, \\ NEPAL \\ ${ }^{3}$ College of Natural Resource Management, Pakhribas, Dhankuta, Department of Agricultural Economics and Agribusiness \\ Management, Agriculture and Forestry University, Rampur, Chitwan, NEPAL \\ ${ }^{4}$ Department of Agricultural Economics, Purdue University, West Lafayette, 47906, Indiana, USA \\ *Corresponding author's E-mail:nblacharya@gmail.com
}

\section{ARTICLE HISTORY}

Received: 11 October 2019

Revised received: 14 November 2019

Accepted: 16 November 2019

\section{Keywords}

Benefit-cost ratio

Cobb-Douglas

Ginger

Productivity

Returns to scale

\section{ABSTRACT}

This study investigates the economics of ginger (Zingiber officinale Rose.) production in the Salyan district of Nepal. The production economics was assessed by the household survey in purposively selected Sharada municipality and Siddhakumakh Rural Municipalities. The semi-structured interview schedule was administered to interview randomly selected fortythree producers from Sharada Municipality and thirty-one producers from Siddhakumakh Rural Municipality. The results indicated that the ginger production was found to be a profitable enterprise in the study area with an average $\mathrm{B}: \mathrm{C}$ ratio of 1.55 . The overall productivity of ginger in the study area was found to be $16.28 \mathrm{MT} / \mathrm{ha}$. The Cobb-Douglas production function indicates that ginger production exhibited increasing returns to scale at a decreasing rate. The regression function of 0.784 implies that if all the inputs specified in the production function are increased by $100 \%$, the gross return will increase by about $78.4 \%$.

(C)2019 Agriculture and Environmental Science Academy

Citation of this article: Acharya, N., Acharya, B., Dhungana, S.M. and Bist, V. (2019). Production economics of Ginger (Zingiber officinale Rose.) in Salyan district of Nepal. Archives of Agriculture and Environmental Science, 4(4): 424-427, https://dx.doi.org/10.26832/24566632.2019.040408

\section{INTRODUCTION}

Ginger (Zingiber officinale Rose.) is a widely grown spice crop of mid-hills of Nepal with a huge export value (ITC, 2007). Ginger as a high-value spice crop can contribute more to improve the socioeconomic status of rural people by raising their income (NSCDP, 2007). It is one of the nineteen commodities of Nepal that has significant export potential (NTIS, 2017). Globally, Nepal is fourth in ginger production after India, China, and Nigeria with about $9.2 \%$ of the world's share (FAO, 2017). About $99 \%$ of Nepal's ginger export is to India, about three fourth of which is fresh ginger rhizome while remaining is in dried form locally known as 'sutho' (TEPC, 2017). The total area under cultivation of ginger in Nepal was 22649 hector (ha) with the production of 279504 Metric Ton (MT) in fiscal year 2016/17 (MoAD, 2018). Salyan is the second most important district of Nepal after the llam district in ginger production. The total area under ginger production in Salyan district in 2016/2017 was
2000 ha with a total production of 25006 MT (DADO, 2018). Salyan district shares $8.95 \%$ of total national ginger production and shares $8.83 \%$ of total cultivated land area (MoAD, 2018). Agricultural development is the key factor of poverty reduction in Nepal and commercialization of the Nepalese agriculture sector can be brought about through increased market research and product development (ADS, 2015). Despite this humongous potential of ginger to alleviate rural poverty, the studies that investigate the profitability of ginger production are lacking. Ginger production is basically a family farm enterprise of smallholder farmers who are facing multi-faceted challenges like increased cost of production, lack of production, sub-optimal level of resource use, lack of market information and inefficient marketing channels (Khanal, 2018). However, studies on economic aspects of ginger production are limited. To fill this gap, this study was conducted to investigate the economics of ginger production in the major ginger-producing pocket of the country. It also explores the level of resource used by the ginger 
producers and identifies the scale of production.

\section{MATERIALS AND METHODS}

\section{Selection of study area}

Among all the districts of Nepal, Salyan district ranks second, after the llam district, both in terms of area under ginger farming and total production (MoAD, 2018). Salyan district, famous for its fibreless ginger, has a promising scope of improving the ginger sub-sector which can lead to employment generation and poverty alleviation if problems of marketing could be solved (FNCCl, 2012). Malneta of Sharada Municipality and Chande of Siddhakumakh Rural Municipality were selected purposively as they were major ginger producing areas in Salyan District (PMAMP, 2018).

\section{Sources of data}

Primary data was collected by conducting a household survey using a semi-structured, pre-tested interview schedule while the secondary sources of data were reports of government authorities, NGOs and INGOs along with research articles on national and international journals and proceedings. The collected information was further verified through a focus group discussion conducted within the study area.

\section{Sample size and sampling techniques}

For the samples of producers, an inventory of farmers of the research study areas was prepared to consult farmers groups/ cooperatives, Project Implementation Unit of Prime Minister Agriculture Modernization Project (PMAMP) and District Agriculture Development Office (DADO). Random sampling technique was used to select 43 producers from Sharada Municipality and 31 from Siddhakumakh Rural municipality.

\section{Data analysis}

The collected data was analyzed using the statistical packages like Microsoft Excel and Statistical Package for Social Science (SPSS version 16). Cobb-Douglas production function was used for the assessment of production economics.

\section{Economic analysis}

Cost of production: Only variable cost items were considered and the total variable cost of production was calculated by adding all the expenditure on variable inputs.

Total variable cost $=$ Rhizome cost + labor cost (land preparation, planting, manure application, weeding, mulching, harvesting, and other post-harvest activities) + Farm Yard Manure (FYM) cost + fertilizer cost + insect-pest management cost

Benefit-cost analysis: The benefit-cost analysis was carried out after calculating the total variable cost and gross returns from ginger production (Poudel et al., 2016). The benefit-cost analysis was carried out by using the formula:

\section{B: C Ratio $=\frac{\text { Gross returns }}{\text { Total variable cost }}$}

Where,

Gross return (in NRs) = total quantity of ginger marketed $(\mathrm{kg}) \times$ price (per $\mathrm{kg}$ ) of ginger + total quantity of sutho $(\mathrm{kg}) \times$ price $($ per $\mathrm{kg}$ ) of sutho + total quantity of seed rhizome $(\mathrm{kg}) \times$ price $($ per $\mathrm{kg}$ ) of seed rhizome

\section{Empirical model}

The extended Cobb-Douglas production function which was used as the empirical model in the study is given below:

$\mathrm{Y}=\mathrm{AX}{ }_{1}{ }^{\mathrm{b} 1} \mathrm{X}_{2}{ }^{\mathrm{b} 2} \mathrm{X}_{3}{ }^{\mathrm{b} 3} \mathrm{X}_{4}{ }^{\mathrm{b} 4} \mathrm{X}_{5}{ }^{\mathrm{b} 5} \mathrm{e}$

Where,

$Y=$ Gross returns, $A=$ Intercept, $X_{1}=$ rhizome cost, $X_{2}=$ labor cost, $X_{3}=$ farmyard manure cost, $X_{4}=$ fertilizer cost, $X_{5}=$ insect pest management cost, $b_{1}$ to $b_{5}=$ elasticity coefficients, $e=$ Error term.

When Cobb-Douglas production function was transferred into linear form, it was expressed as:

$\ln Y=\ln A+b_{1} \ln X_{1}+b_{2} \ln X_{2}+b_{3} \ln X_{3}+b_{4} \ln X_{4}+b_{5} \ln X_{5}+e$

Returns to scale in Cobb-Douglas function is determined by the sum of the power coefficients i.e. $b 1+b 2+\ldots+b n$

If $b 1+\ldots+b n=1$, we have constant return to scale.

If $\mathrm{b} 1+\ldots+\mathrm{bn}<1$, we have decreasing return to scale.

If $b 1+\ldots+b n>1$, we have increasing return to scale. The values of the input coefficient imply their contribution to the production of ginger. Similarly, the Cobb-Douglas production frontier has been used to investigate the resource use analysis by Islam et al. (2012) and Poudel et al. (2016).

\section{RESULTS AND DISCUSSION}

\section{Productivity and production of ginger}

The overall productivity of ginger in the study site was found to be $16.28 \mathrm{MT} / \mathrm{ha}$. It was recorded higher than the average productivity of the district (12.50 MT/ha) and the national average (12.34 MT/ha) (MoAD, 2018). The study area is identified as one of the most productive areas in the country for ginger and has huge climatic suitability for ginger production. Malneta (17.09 MT/ha) was found to be significantly superior to Chande (15.15MT/ha) in terms of ginger productivity. The overall average production of ginger by each farm was found to be $2080.40 \mathrm{~kg}$ which statistically similar in both the villages (Table 1)

\section{Quantity of ginger traded (rhizome, sutho and seed)}

In the study area, ginger was found to be traded in three different forms. They were: mature rhizome, the dried form of rhizome (locally known as 'sutho') and seed rhizome. One kilogram of sutho can be obtained by drying about $6 \mathrm{~kg}$ of the 
Table 1. Productivity and production of ginger in the study site.

\begin{tabular}{lllllll}
\hline Variable & $\begin{array}{l}\text { Malneta } \\
(\mathrm{N}=43)\end{array}$ & $\begin{array}{l}\text { Chande } \\
(\mathrm{N}=31)\end{array}$ & Overall & Mean difference & t value & $\mathbf{p}$ value \\
\hline Productivity (MT/ha) & 17.09 & 15.15 & 16.28 & $1.931^{* * *}$ & 3.936 & 0.000 \\
Production of ginger $(\mathrm{kg})$ & 2176.75 & 1946.75 & 2080.40 & 229.969 & 0.656 & 0.514 \\
\hline
\end{tabular}

Note: ${ }^{* *}$ indicate level of significance at $1 \%$ level.

Table 2. Quantity of ginger sold (fresh mature rhizome, Sutho and Seed).

\begin{tabular}{lllllll}
\hline Quantity (kg/ha) & $\begin{array}{l}\text { Malneta } \\
(\mathrm{N}=43)\end{array}$ & $\begin{array}{l}\text { Chande } \\
(\mathrm{N}=31)\end{array}$ & Overall & Mean difference & t value & $\mathrm{p}$ value \\
\hline Fresh rhizome & 11534.88 & 11881.72 & 11680.18 & 346.836 & -0.501 & 0.618 \\
Dried form & 923.25 & 614.73 & 794.00 & $308.52^{* *}$ & 2.066 & 0.042 \\
Seed rhizome & 975.19 & 109.67 & 116.90 & $612.61^{* *}$ & 3.208 & 0.002 \\
\hline
\end{tabular}

${ }^{* *}$ indicate level of significance at $5 \%$.

Table 3. Cost of production per hectare, revenue and B:C ratio of ginger.

\begin{tabular}{lllllll}
\hline Cost (NRs) & $\begin{array}{l}\text { Malneta } \\
(\mathrm{N}=43)\end{array}$ & $\begin{array}{l}\text { Chande } \\
(\mathrm{N}=31)\end{array}$ & Overall & $\begin{array}{l}\text { Mean } \\
\text { difference }\end{array}$ & t value & p value \\
\hline Rhizome cost & 71534.88 & 72946.23 & 72126.126 & -1411.352 & -0.462 & 0.645 \\
Labor cost & 100279.06 & 77338.70 & 90668.918 & 22940.360 & $4.734^{* * *}$ & 0.000 \\
FYM cost & 22325.58 & 21045.69 & 21789.414 & 1279.882 & 0.586 & 0.560 \\
Fertilizer cost & 372.09 & 0.00 & 216.216 & 372.093 & $1.992^{*}$ & 0.050 \\
Insect-pest & 5174.80 & 7339.90 & 3349.774 & 4356.526 & $3.227^{* *}$ & 0.002 \\
management cost & & & & & 0.000 \\
Total cost of production/ha & 199686.43 & 172148.92 & 188150.450 & 27537.509 & $4.705^{* * *}$ & 0.000 \\
Return & 330000.00 & 238899.99 & 291836.48 & 91100.00 & $6.111^{* * *}$ & 0.001 \\
B:C ratio & 1.67 & 1.39 & 1.557 & 0.280 & $3.317^{* * *}$ & 0.001 \\
\hline
\end{tabular}

Note: ${ }^{* * *},{ }^{* *},{ }^{*}$ indicate level of significance at and $1 \%, 5 \%$ and $10 \%$ respectively.

Table 4. Cobb-Douglas production function of ginger production.

\begin{tabular}{lllll}
\hline Variables & Coefficient & Standard error & t-value & p-value \\
\hline Constant & $6.760^{* * *}$ & 2.038 & 3.320 & 0.001 \\
Rhizome cost & 0.125 & 0.148 & 0.845 & 0.401 \\
Total labor cost & $0.220^{* *}$ & 0.085 & 2.596 & 0.012 \\
FYM cost & 0.167 & 0.133 & 1.255 & 0.214 \\
Fertilizer cost & 0.012 & 0.013 & 0.989 & 0.326 \\
Insect pest management cost & $0.260^{* * *}$ & 0.007 & 3.818 & 0.000 \\
F-value & 12.920 & & & \\
R square & 0.487 & & & \\
Adjusted R-square & 0.449 & & \\
Return to scale & 0.784 & & \\
\hline
\end{tabular}

Note: ${ }^{* * *},{ }^{* *}$ indicate level of significance at and $1 \%$ and $5 \%$, respectively.

fresh mature rhizome. The overall average quantity of fresh ginger marketed on the per hectare basis was reported to be $11680.18 \mathrm{~kg}$. The quantity of fresh mature rhizome sold was found to be more in Malneta (11534.88 kg) than Chande $(11881.72 \mathrm{~kg})$. The quantity of marketed sutho was significantly higher in Malneta $(923.25 \mathrm{~kg}$ ) compared to Chande (614.73 kg). Similarly, the quantity of seed rhizome marketed was found to be significantly more in Malneta $(975.19 \mathrm{~kg}$ ) than that in Chande (109.67 kg) (Table 2).

Estimation of cost of production, revenue, and B: C ratio of ginger

The average cost of ginger production was estimated to be NRS. 188150.45 (USD 1636.09) per hectare. The cost of production in Malneta (NRs 199686.43 = USD 1736.40) was found significantly more than that of Chande (NRs $172148.92=$ USD 1496.95). The average returns from ginger in the study area were estimated to be NRS. 291836.48 (USD 2537.71) per hectare. The farmers of Malneta (NRs $330000=$ USD 2869.56 per hectare) were recognized to be generating significantly higher returns than that of the ginger producers of Chande (NRs $238899.99=$ USD 2077.39 per hectare). The overall B:C ratio of producers was calculated to be 1.55 which indicates that ginger production is a profitable business in the study area. $\mathrm{B}: \mathrm{C}$ ratio was found to be significantly higher in Malneta (1.67) as compared to Chande (1.39). Similar findings of profitability in ginger production were also reported by Poudel et al. (2016), Timsina (2010) (Table 3). 
Cobb-Douglas regression analysis of ginger production

The estimated values of the coefficients and related statistics of Cobb-Douglas production functions are shown in Table 4. Out of five independent variables included in regression analysis, the costs on insect-pest management and labor were found significant while rhizome, farmyard manure, and fertilizer costs were not found significant in the study area. Poudel et al. (2016) also reported labor costs to be significant in ginger production. The regression coefficient of insect-pest management cost was 0.26 which indicates that increasing $100 \%$ cost in insect-pest management, the gross returns could be increased by 0.26 . Similarly, a $100 \%$ increase in labor costs could increase the gross returns by $22 \%$. The sum of all the regression coefficients of all the inputs considered in the regression function was estimated to be 0.784 which indicates that the production function exhibited an increasing return to scale at a decreasing rate. This implies that if all the inputs specified in the production function are increased by unity, the gross return will increase by about 0.784 . The adjusted R-square value was estimated to be 0.449 which implies that the specified variables affect gross return by $44.9 \%$.

\section{Conclusion}

Higher productivity indicates better suitability of ginger farming in the study area. Similarly, the benefit-cost ratio of 1.55 demonstrates the higher profitability of the ginger production enterprise. The Cobb-Douglas regression model revealed that ginger production exhibited an increasing return to scale at a decreasing rate. The regression coefficient of 0.784 implies that if the specified cost variables in the production function are increased by unity, the gross return will increase by 0.784 units. The costs on insect pest management and labor costs were identified to be significant for increasing the revenue. This implies that increasing labor and insect pest management costs will significantly increase the returns from ginger production.

\section{ACKNOWLEDGEMENTS}

The authors acknowledge Agriculture and Forestry University, Rampur, Chitwan, Nepal and Ginger Zone Implementation Unit, Salyan of Prime Minister Agriculture Modernization Project for jointly sponsoring this research project.

\section{Conflict of interest}

The authors hereby declare that they possess no conflict of interest in this research project.

Open Access: This is an open access article published under the terms and conditions of Creative Commons AttributionNonCommercial 4.0 International License which permits noncommercial use, distribution, and reproduction in any medium, provided the original author(s) if the sources are credited.

\section{REFERENCES}

ADS. (2015). Agriculture Development Strategy (ADS) 2015 to 2035. Ministry of Agricultural Development, Singhadurbar. Kathmandu.

DADO. (2018). District Agricultural Profile Book 2017/18. District Agricultural Development Office. Salyan.

FAO. (2017). Nepal: Ginger production. Food and Agriculture Organizations of the United Nations. Rome.

FNCCI. (2012). One District One Product: Balanced Economic Growth. Federation of Nepalese Chambers of Commerce and Industry, Agro Enterprise Center. Kathmandu.

Islam, Q.M., Matin, M.A. and Hossain, S. (2012). Economic performance of ginger (Zingiber officinale Rose.) cultivation in some selected locations of Bangladesh. Bangladesh Journal of Agricultural Research, 37(1): 109-120.

ITC. (2007). Export Potential Assessment in Nepal. Market Analysis Section. International Trade Center. Kathmandu.

Khanal, K. (2018). Factors Affecting and marketing chain of ginger in Salyan District, Nepal. International Journal of Applied Sciences and Biotechnology, 6 (2): 127-131, https://doi.org/10.3126/ijasbt.v6i2.xxxxx

MoAD. (2018). Statistical Information on Nepalese Agriculture 2016/2017. Ministry of Agricultural Development, Singhadurbar. Kathmandu.

NSCDP. (2007). Spice Crops, An Annual Report for 2007. National Spice Crops Development Program. Khumaltar. Lalitpur.

NTIS. (2017). Nepal Trade Integration Strategy Factsheet. Trade Promotion Programme. Kathmandu.

PMAMP. (2018). Ginger zone profile. Prime Minister Agricultural Modernization Project - Zone Implementation Unit (Ginger). Salyan.

Poudel, R.R., Regmi, P.P., Thapa, R.B., Chhetri, Y.D.G. and Chhetri, D.B.K. (2016). Economic analysis of ginger cultivation in selected locations of Palpa, Nepal. Azarian Journal of Agriculture, 3(6): 135-140.

Singh, S. and Dhillon, S.S. (2015). Socio-Economic analysis of ginger crop in Himachal Pradesh. Indian Journal of Hill Farming, 28(1): 35-42.

TEPC. (2017). Ginger Factsheet. Kathmandu: Trade and Export Promotion Centre, Government of Nepal.

Timsina, K.P. (2010). Economics of ginger production: A case study of Makawanpur district, Nepal. Journal of the Institute of Agriculture and Animal Sciences, 1: 35-41. 